\title{
ALK Protein Variant
}

National Cancer Institute

\section{Source}

National Cancer Institute. ALK Protein Variant. NCI Thesaurus. Code C133463.

A variation in the amino acid sequence for the ALK tyrosine kinase receptor protein. 